\title{
Managerial Overconfidence and Investment Decision: Empirical Validation in the Tunisian Context
}

\author{
Halim Smii ${ }^{1, ~ *}$, Mondher Kouki ${ }^{2}$, Hayet Soltani ${ }^{3}$ \\ ${ }^{1}$ Faculty of Economics and Management, University of Tunis El Manar, Tunisia \\ ${ }^{2}$ Faculty of Management and Economics Sciences of Tunis, Tunis-El Manar, Tunisia \\ ${ }^{3}$ Faculty of Economics and Management of Sfax, Department of Economic and Management Laboratory (LEG), University of Sfax, Sfax, \\ Tunisia
}

\section{Email address:}

smiihalim@gmail.com (H. Smii), hayetsoltani91@yahoo.fr (H. Soltani), Mondher.kouki@fsegt.rnu.tn (M. Kouki)

${ }^{*}$ Corresponding author

\section{To cite this article:}

Halim Smii, Mondher Kouki, Hayet Soltani. Managerial Overconfidence and Investment Decision: Empirical Validation in the Tunisian Context. International Journal of Finance and Banking Research. Vol. 7, No. 4, 2021, pp. 82-94. doi: 10.11648/j.ijfbr.20210704.11

Received: July 17, 2021; Accepted: August 6, 2021; Published: September 4, 2021

\begin{abstract}
Nowadays and especially after the revolution and the troubles that Tunisia has witnessed, the investment phenomenon has been affected and remains inefficient. Indeed this inefficiency is due to an excessive investment behavior. However, this issue has been discussed under the influence of behavioral finance. We explore that the manager's overconfidence can explain his behavior when it comes to business investment. The objective of this investigation is to examine the effect of managers' personal characteristics, namely overconfidence, on the investment decision of 45 Tunisian listed companies from 2009 to 2018 . We construct a proxy made up of both the remuneration of the directors and his decisionmaking power to measure the excess of managerial confidence and we use the Richardson model to measure the volume of investment. Our empirical results give the following conclusion: A positive and significant relationship between the manager's overconfidence and the investment volume of listed Tunisian companies.
\end{abstract}

Keywords: Manager Skill, Overconfidence, Free Cash-Flow, Investment Cost, Decision-making

\section{Introduction}

The questioning of the rational person hypothesis by modern financial theory and the rise of behavioral finance constitute a research debate on the irrational behavior of managers concerning their decisions in the company. Indeed, the introduction of psychology into finance remains a fruitful area. Overconfidence, which leaders display in their decision-making, is one of the most documented and widely used personal characteristics in the human behavior literature. Indeed, when managers are subject to a kind of psychological bias, their firms may be in a suboptimal state, since in this case, as managers think they are promoting the value of their firms, they actually reduce it.

Nevertheless, many empirical studies have focused on the strategic decisions of the firm, namely investment decisions, financing decisions and dividend distribution decisions, in relation to the irrational behavior of managers.
The work of Baker, Ruback and Wurgler [1] concluded that in a company, there is a negative relationship between managers 'over confidence and their financial decisions. In this sense, the work of Hackbarth, Heaton, Malmendier et al. focused on investment and financing decisions [2-4]. For their part, Malmendier and Tate [5], examined merger and acquisition decisions. In contrast, research on dividend policy choice is scarce, ((Cordeiro, Deshmukh et al. [6] and [7]).).

The misalignment of the interests of managers and shareholders (Jensen and Meckling [8], as well as the asymmetry of information between the actors of the company and the capital market (Myers and Majluf [9]), are the main causes that can explain the distortions in the investment policy. Jensen and Meckling [8], focused on the personal benefits reaped by managers by investing in different projects. While Myers and Majluf [9] explained the investment distortions by the asymmetry of information between the capital market and the different insiders of the firm. In fact, asymmetric information and agency problem simply that the 
managers of firms limit external financing to avoid a decrease in the value of the (undervalued) shares of their firms, which thus depend on the capital structure. Therefore, the more investment is increased by cash-flow, the more the distortion is reduced. With regard to the control of investment opportunities, the empirical work of Fazzari, Hubbard and Peterson [10] has shown the robustness and existence of the investment cash flow sensitivity. However, the conclusion of Hubbard and Peterson [11] and that of Kaplan and Zangales [12, 13], Fazzari, remain controversial in most of their applications to investment-cash flow sensitivity, because of the imperfection of the capital market. Several previous works such as (Kahneman and Lovallo, Shefrin, Goel and Thakor, Malmendier and Tate, Heaton, Gervais, Heaton and Odean, Hackbarth [14-17, 3, 18, 2]), have argued that the overconfidence bias plays a central and important role in the investment decision. However, the managerial overconfidence bias makes firms' investment volume more sensitive to cash flow.).

Conducting a comprehensive literature review on investment-related cash flow sensitivity in behavioral finance, Malmendier and Tate [19], Campbell et al. [20], Lin et al. [21], Wei Huang et al. [22], Glaser and Schmitz [23], concluded that management overconfidence bias, leads to investment-related cash flow sensitivity and that this sensitivity will be greater for constrained firms. Similarly, Malmendier and Tate [24, 25], Campbell et al. [20], Lin et al. [21] and Wei Huang et al. [22], have shown that management overconfidence bias, creates sensitivity between firm investment and internal cash flows.

More interestingly, El GaiedMoez and Zgarni Amina's [26] studies, investigating the relationship between free cash flow and managerial overconfidence, found that highly confident managers with positive free cash flow tend to overinvest significantly more than those who are highly confident but with negative free cash flow.

Let us note that if investment is a value-creating factor, as argued by (Camerer, C., \& Lovallo, D. [27]), it constitutes, according to McConnell and Muscarella, [28], a good opportunity for expansion for a company. Nevertheless, it is a long-term investment, with too high a risk, which can lead to a conflict of interest between shareholders and managers, due, in the opinion of Byrd et al. [29],, to risk aversion and the existence of a planning perimeter between the actors of the company. Indeed, managers may not have the objective of investing, nor consider doing so, while executives have a short-term preference (i.e. the period during which they run the company), compared to directors, who have a longer vision associated with the infinite life of the company.

The empirical work of Narayanan [30], has revealed that executives prefer short-term investment projects that are likely to quickly reveal the performance of these investments and eliminate uncertainty about their own value in the labor market. Additionally, these managers typically reduce capital expenditures to increase short-term performance, thereby protecting themselves from the threat of control, usually associated with falling stock prices, (Thurow [31]). It is worth noting that managers and shareholders have quite different levels of risk aversion.

Shareholders prefer top diversified portfolios while managers do not. Because of the high uncertainty about the returns from investment projects, managers tend to avoid risky projects, which can be detrimental to their careers. This can lead to myopic investment behavior (Porter, [32]) and cause problems in the efficient allocation of the firm's resources (Jensen and Meckling, [8]).

In this paper we try to suggest an alternative explanation for the sensitivity of investment to cash flow and non-optimal investment behavior in the framework of behavioral finance. Instead, we concentrate on the personal characteristics of key decision makers, namely the managerial overconfidence within firms and its impact on the volume of investments.

The remainder of the article is organized as follows. The second section summarizes previous research on managerial overconfidence, financing decisions, and investment. Section three provides a detailed description of the sample, data sources and empirical modeling. Section four shows the findings after testing the two empirical models of our research. Section 5 presents interpretation and estimation results discussion and finally concluding remarks.

\section{Literature Review and Measurement of Overconfidence}

\subsection{Literature Review}

A large literature has suggested that individuals exhibit overconfidence in individual decision making. One wellestablished stylized effect is the "better than average" effect: when people compare their skills to those of their peers, they tend to overestimate their insight relative to the average (Larwood and Whittaker, Svenson, and Alicke, [33-35]).

Excessive confidence, in the form of the "above-average effect", also affects the attribution of causation. Because individuals expect their behavior to produce success, they are more likely to attribute good results to their actions. Experimental studies have shown that executives are particularly prone to display overconfidence, both in terms of an "above-average effect" and in terms of a "narrow confidence interval" (Kidd [36]). The literature proposes three main reasons for this finding. First, individuals are more confident about outcomes that they judge to be under their control (Weinstein [37]). Indeed, a CEO who has selected an investment project is likely to underestimate the probability of a bad outcome (March and Shapira, Langer [38, 39]). Second, individuals are particularly confident in outcomes to which they are highly committed (Weinstein [39]). Third, overconfidence is likely to be strongest when it is difficult to compare performance across individuals and when the reference point is abstract (Alicke et al. [40]). Based on hybrid theory, Richard [41], predict that management overconfidence can affect firm decisions. More recently, Heaton [3] proposes a simple model of corporate finance by introducing managerial optimism. He predicts that 
the corporate manager's optimism may have explanatory power for decision making, as it may lead to a sensitivity of cash flows to investment. With optimistic managers, firm investment should be interacted with firms' internal funding sources. Heaton [3] links CEO optimism to the financing decision.

Optimistic managers are assumed to be less rational than traditional behavioral finance models. They believe that the projects of the companies under their control are better than they really are. In this case, managers will attribute to these projects an expected return higher than their real value. In Heaton's model [3] model, managers with an optimism bias are described as believing that stock issuance will be systematically underestimated by outside investors. Companies will use internal cash to fund their investment opportunities because the funding appears to be costless with management optimism. This will lead to a cash investment phenomenon. Malmendier and Tate [25] propose a model in which they introduce a management overconfidence bias and conclude that the sensitivity of cash flows to investment exists, and is robust, in a sample of large US firms. Indeed, these authors have shown empirically that management overconfidence increases the sensitivity of firms' investments to the availability of internal cash flows.

Such a conclusion could explain the problems of over investment and under-investment. The distortions in firms' investment policies may be influenced by managerial optimism that makes it dependent on internal cash flows. Managers will invest intensively when cash flows are abundant, facing frictions of over-investment. They will under invest when internal funds are insufficient. This leads to underinvestment behavior that is a direct consequence of managers' overconfidence in high-cost external funding sources.

Malmendier and Tate [25] empirically validated apredictionby Heaton [3] that there is a sensitivity of firms' investment policies to internal sources of finance. This relationship depends on firms' financial constraints. Using the Kaplan and Zingales (KZ) measure of financial constraints, Malmendier and Tate [25] find that CEO overconfidence increases the sensitivity of investment to cash flow, and this is especially true for more constrained firms. As a matter of fact, companies may encounter great difficulties when they wish to finance their projects with external funds. The cost of external financing will then be higher than that of other less constrained companies. For this reason, confident managers prefer internal funds. The sensitivity of firms to internal cash flows for their investments will be intense when firms are financially constrained. According to Hovakimian, A., and Hovakimian, G.[44], financial constraints concern firms with restrictive and expensive access to external capital markets, which should rely more on internal funds to finance their investment policies.

Malmendier and Tate [25] proposed a measure of management overconfidence and concluded that sensitivity to investment cash flows persists in the U.S. context. This result is robust even when the overconfidence measures are modified.
All studies reviewed in this area speak to a positive relationship between investment and firm cash availability. Campbell, Johnson, Rutherford, and Stanley [43], with minor substitutions to the governance control variables, due to a data availability issue, confirmed Malmendier and Tate's finding that firms with optimistic managers have much greater sensitivity to investment cash flows in the U.S. context. In the same context and in an initial study in the United States, Lin, $\mathrm{Hu}$ and Chen [21], studied the impact of management confidence on firms' investment activities. Among companies listed on the Taiwan Stock Exchange, they found a positive correlation between investment and internal cash flow. On the contrary, the literature has documented a positive correlation between top management overconfidence and investment cash flow sensitivity, without any assumption on the agency cost. Indeed, Wei Huang et al [22], proposed a misalignment of managerial and shareholder interests on how agency costs may affect the relationship between top management overconfidence and investment cash flow sensitivity using data from listed companies in China between 2002 and 2005. Their work, investigates whether the sensitivity of investment cash flows differs between state-controlled and non-state-controlled companies with agency costs showing a significant difference. For Huang et al. [22], the results show that overconfidence by key managers leads to increased sensitivity of investment cash flows. However, this relationship is not significant for nonstate controlled firms. This is because state-controlled firms have a significantly higher agency cost than state-controlled firms when regressing with an agency cost proxy. Additional tests show that the positive effect of management overconfidence on the sensitivity of investment cash flows holds only for firms with high agency costs. After this comprehensive analysis of investment cash flow sensitivity in behavioral finance, the empirical results of Glaser and Schmitz, Campbell et al. and Wei Huang et al. [23, 20, 22], allow us to conclude that management overconfidence bias leads to investment cash flow sensitivity and that this sensitivity will be greater for constrained firms. We can summarize the above predictions through the hypothesis that derives from the theoretical predictions of Heaton [3], and several empirical validations (Malmendier and Tate, Campbell et al., Lin et al., Wei Huang et al. [24, 25, 20, 21, 22]), which show that management overconfidence bias creates a sensitivity between firm investment and internal cash flows.

For this reason, our first hypothesis will be directed to test empirically, the validity and robustness of this prediction: the most confident CEOs will perceive that their shares are undervalued and financing an investment project with external funding sources will make it expensive. El Gaied Moez and Zgarni Amina [26], studying the relationship between free cash flow and managerial overconfidence, concluded that highly confident managers with positive free cash flow tend to overinvest much more than those who are highly confident and have negative cash flow. This result, similar to Barros and Silveira [44], shows that overconfident managers overestimate their capabilities and overemphasize their personal information and perspective. Xiao and Zhou 
[45], improved on this hypothesis and showed that managerial overconfidence is not an essential part of good investment decision making. They showed that managerial overconfidence, combined with free cash flow, amplifies overinvestment spending.

H1. The investment of the overconfident manager is more sensitive to cash flow than the investment of the not overconfident manager.

\subsection{Measurement of Overconfidence}

The capital budgeting model, developed by Gervais et al., [46], studied the effect of managerial overconfidence on firms' investment policy. Heaton's theory [3] constitutes an empirical research center for Mlamendier and $\mathrm{Al}$ [47]. The latter, were the first to use the ownership status of managers in this variable to measure the degree of managerial overconfidence for their empirical tests. To test data in Taiwan, Lin et al [21], adopted a similar method. They apply the findings of the managers and the company's profit to measure the variance of the variables to measure managerial overconfidence.

In the Tunisian context, it is difficult to find alternative variables to the managerial overconfidence to study the impact of this overconfidence on the investment decision of Tunisian companies. Indeed, the index of profit estimates, important and relevant information, difficulties in finding the necessary data, media reports do not reflect reality in other words, are not adapted to the real situation in Tunisia. Thus, in order to study the irrational behavior of the manager in corporate investment, it is difficult to find a variable related to managerial overconfidence.

On this basis, we construct a proxy composed of both the manager's compensation and his decision power. The latter is measured by the inverse of the number of managers in the management team. All else being equal, the lower the number of managers, the greater the manager's decision-making power. This second component of our chosen proxy, decision power, draws its logic from the fact that it gives the manager a sense of being the most important and the primary decision maker, which may lead him or her to overestimate his or her abilities and skills. (Brown and Sarma, Doukas and Petmezas, Jenter, and Jin and Kothari, [48-51]).

Hence, our main indicator of executive dominance (Dom1) is the natural logarithm of the ratio of the CEO's total annual compensation to the firm's total assets:

$$
(\text { Dom })=\log \frac{\text { rémunération total }}{\text { actif total }}
$$

\section{Empirical Modeling}

\subsection{Empirical Model Presentation}

Our empirical study consists in testing the effect of the overconfidence of the managers on the decision of investment within the Tunisian firms through a panel model during the period 2009 to 2018 for 45 firms constituted by a dependent variable and a determined number of independent variables. Thus, to test the effect of managers overconfidence on the investment decision within the firm is based on the following model:

$$
\begin{array}{r}
I_{i, t}=\beta_{1} I_{i, t-1}+\beta_{2} \text { EC }_{i, t}+\beta_{3} \text { Growth }_{i, t}+\beta_{4} \text { Leverage }_{i, t}+ \\
\beta_{5} \text { Cash }_{i, t}+\beta_{6} \text { Age }_{i, t}+\beta_{7} \text { Size }_{i, t}+\beta_{8} \text { Stock Returns }_{i, t}+\varepsilon_{i, t}(2)
\end{array}
$$

With:

1) $i$ : Indicates companies $(i=1,2, \ldots, 45)$

2) $t$ : Index of years $(t=1,2, \ldots .10)$

3) $\alpha$ : Constant

4) $\beta$ : Parameters to be estimated

5) $I_{i t}:$ is the total capital expenditure, measured as the sum of all capital expenditures, acquisitions and research and development less receipts from the sale of property, plant and equipment for enterprise $\mathrm{i}$ in year $\mathrm{t}$;

6) $E C_{i t}$ : Overconfidence is the degree of overconfidence of managers for company $i$ in year $t$;

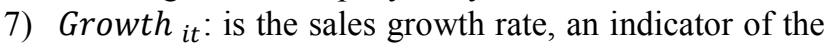
investment opportunity for firm $i$ in year $t$;

8) Leverage ${ }_{i t}$ : is the ratio of the sum of book value of short-term and long-term debt to total assets for firm i in year $\mathrm{t}$;

9) Cash $_{i t}$ : is the level of liquidity, measured as the balance of cash and short-term investments over total assets for firm $i$ in year $t$;

10) Age $_{i t}$ : is the age of firm $i$ in year $t$;

11) Size $_{i t}$ : is the size of firm $i$ in year $t$;

12)Stock Returns ${ }_{i t}$ : is the stock return for the year preceding the year of investment. It is measured as the change in the market value of the company compared to the previous year.

13) $\varepsilon$ : Error term

Our objective from this empirical model is to estimate the impact of overconfidence of mangers on the investment decision within firms according to the measures of microeconomic variables specific to Tunisian firms.

\subsection{Variables Definition}

1) Dependent variable: The variable that we seek to explain in our work is the ratio of total investment expenditure of the company. In the literature, there are many ways to calculate the investment ratio. Richardson [52] used a measure expressed by the investment overrun. In our work, we will use the total of all purchases and construction of the company's fixed assets, intangible assets and other long-term assets paid in cash, consisting of subsidiaries and other business units to pay in cash, capital expenditure paid in cash and with the ratio of total assets at the beginning of the year as total investment.

The total investment can be decomposed into two parts: a first part related to the investment in a new positive NPV planned expenditures and a second part related to the additional investment on capital expenditures. Finally, the firm's excess investment is expressed as the difference between the actual level of capital investment and the expected level of capital investment (Table 1). 


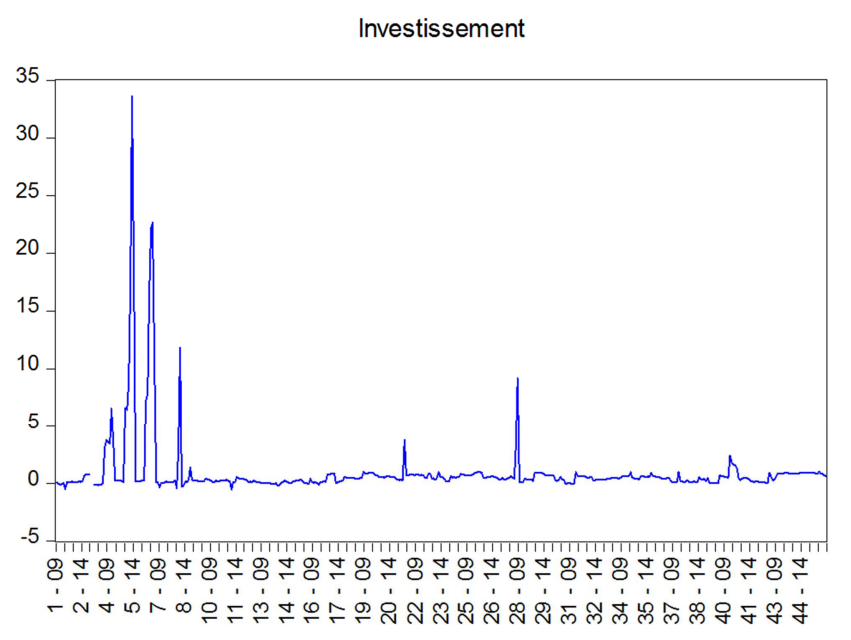

Figure 1. The evolution of investment ratio of Tunisian Companies Listed on the Stock Exchange during 2009-2018.
We tried to study the variation of the investment ratio measured for the firms in our sample during the whole study period (2009-2018). The figure above shows that the investment ratio was characterized by a successive increase from 2009 until 2018. The total investment ratio increased until reaching a maximum of 33.603 during the study period, with a small decrease -0.520 during the same period 2009 2018 for the 45 Tunisian companies used in our study. But, the increase of this variable did not last more than a few years since this ratio of total investment resumes its level in the average of 0.930 .

If we take into account the outbreak of the Tunisian revolution in 2011, the investment ratio generates a small decrease for this year, then it resumes its development one year later and until 2018. This study has shown that the total investment ratio of Tunisian companies listed on the stock exchange is no longer stable and it changes from one period to another.

Table 1. Definition and measurement of the dependent variable.

\begin{tabular}{llll}
\hline Dependant Variable & Code & Definition & Measure \\
\hline $\mathrm{Y}$ & ITotal & $\begin{array}{l}\text { Capital expenditure } \\
\text { ratio investment total }\end{array}$ & $\begin{array}{l}\text { The sum of all capital expenditures capital expenditures, acquisitions and research and } \\
\text { development less revenues from the sale of sale of property, plant and equipment / Total assets }\end{array}$ \\
\hline
\end{tabular}

2) Independent variables:

As noted, our objective is to use a measure of managerial overconfidence to investigate its effect on the firm's investment decision. The explanatory variable $X_{n}$ is accompanied by control variables summarized in the following table.

Table 2. List of explanatory and control variables.

\begin{tabular}{|c|c|c|c|}
\hline Variable & Code & Calculation Method & Expected Sign \\
\hline \multicolumn{4}{|c|}{ The explanatory variable } \\
\hline Overconfidence & $\mathrm{EC}$ & $\begin{array}{l}\text { In our study, we will construct a proxy composed of both executive decision power and } \\
\text { compensation. The latter being measured by the logarithm of total annual compensation. } \\
\text { (Brown and Sarma, Doukas and Petmezas, Jenter, Jin and Kothari, }[48,49,50,51]) \text {. }\end{array}$ & $(+)$ \\
\hline \multicolumn{4}{|c|}{ The control variables } \\
\hline Growth & Growth & Sales growth rate is an indicator of investment opportunity. & $(-)$ \\
\hline Leverage effect & Leverage & The balance of cash and short-term investments in relation to total assets. & $(-)$ \\
\hline Liquidity level & $\mathrm{CASH}$ & The balance of cash and short-term investments in relation to total assets. & $(+)$ \\
\hline Size & Company size & Log of total assets measured at the beginning of the year. & $(+)$ \\
\hline Age & Age of the company & Log of the number of years that the company has been established. & $(-)$ \\
\hline Stock returns & Share & $\begin{array}{l}\text { The stock returns for the year prior to the investment year. It is measured as the variation of } \\
\text { the market value of the company compared to the previous year. }\end{array}$ & $(+)$ \\
\hline
\end{tabular}

\subsection{Model Specification}

In order to avoid the problem of correlation between the endogenous dependent variable and the error term, several methods have been proposed:

1) Andersonand Hasio's method [53]

Anderson and Hsiao propose the Generalized Moment Method [53]. They attempt to instrument this variable in first differences, $\Delta Y_{i, t-1}$, by its delays in levels, $Y_{i, t-2}$, or in differences, $\Delta \mathrm{Y}_{\mathrm{i}, \mathrm{t}-2}$. Sevestre and Trognon [54] have shown that in the case where the residuals are not auto-correlated, these two instruments are strongly correlated with $\mathrm{Y}_{\mathrm{i}, \mathrm{t}-1}-\mathrm{Y}_{\mathrm{i}, \mathrm{t}-2}$, but are uncorrelated with $\varepsilon_{\mathrm{i}, \mathrm{t}}-\varepsilon_{\mathrm{i}, \mathrm{t}-1}$. For this reason, the estimator obtained by this method is convergent but is not efficient because it does not take into account the structure of the error term and does not exploit all the conditions on the moments.

2) Blundell and Bond's method [55]

Blundell and Bond [55] propose estimation by the Generalized Moments Method in System (GMM system). This method is based on Monte Carlo simulations. The authors have shown that the GMM system estimator is more efficient than the GMM in differences (Arellano and Bond ([56]), which exploits only the moment conditions of the first difference equation with level lagged variables as instruments.

\section{Empirical Results}

\subsection{Descriptive Analysis}

Before conducting our estimation work, we first introduce some descriptive analyses of the different measures retained in our modeling. 
Table 3. Descriptive analysis of continuous variables

\begin{tabular}{llllllllll}
\hline & Invest & Overconfid & Liquidity level & Leverage effect & Size & Growth & Age & FCF & Stock. Ret \\
\hline Mean & 0,928 & 0,946 & 0,082 & 0,687 & 17,211 & 0,104 & 3,472 & 1,002 & 0,359 \\
Max & 33,603 & 46,161 & 2,45 & 78,652 & 21,582 & 3,552 & 4,624 & 553,179 & 15,817 \\
Min & $-0,52$ & $-1,796$ & 0 & $-14,825$ & 6,293 & -1 & 0 & $-6,44$ & $-14,58$ \\
St. Dev & 2,807 & 3,48 & 0,147 & 5,669 & 3,071 & 0,313 & 0,755 & 26,161 & 2,159 \\
\hline
\end{tabular}

The results of the descriptive statistics of the different variables, presented in Table 3 revealed that the explanatory variables have very low standard deviations; however there is a weak link between them. Likewise for the dependent variables of the different research models, there is low variability, which confirms the homogeneity of these variables. First, a review of descriptive statistics reveals that Tunisian companies invest an average of $9.28 \%$ of their assets. The level of liquidity averages $8.2 \%$ of total assets. All the more so, we mention that the average short and long term debt is equal to $68.7 \%$ of total assets, its value is between a minimum of -14.825 and a maximum of 78.652 , this- 18- shows that the debt level is too high in some Tunisian companies.

This is consistent with the fact that the policy of Tunisian firms is based mainly on debt as a source of financing. This is consistent with what Hergli and Teulon [57] indicate in their study "Determinants of the capital structure: the Tunisian case".

The average size of the variable "Sales Growth" of Tunisian companies is 0.104 , this variable has a "maximum" value of 3.552 and a "minimum" value of -1 . Regarding the age of the company, which is measured by the logarithm of the number of years since the date of its creation, it is equal to 3.47 on average. From this table, we also show that the size of the firm is on average 17.21. Finally, the variation of the market value, it presents an average of 0.359 . These results support the idea that the Tunisian firms, which make up our sample, create a favorable ground for testing the sensitivity between investment and the different explanatory variables of our empirical model.

For the first independent variable, the manager's overconfidence, we see that the mean the average is 0.081 . In this respect, it seems that the manager has an overconfidence that can harm the rest of the company's stakeholders. Finally, the second and last independent variable also presents interesting statistics interesting statistics on the level of free cash flow. The free cash flows of Tunisian firms constitute on average $1.002 \%$ of total assets. This last result is also interesting, because the presence of FCF gives suggestions on the risk of overinvestment. The results of the descriptive statistics of the different variables presented in the tables above revealed that the endogenous variables have almost equal standard deviations. Similarly for the exogenous variables, their standard deviations are close, which tells us about the homogeneity of the realizations of these variables. In other words, this ratio differs significantly from one year to another.

\subsection{Correlation Matrix}

The correlation matrix allows us to study the existence (or not) of the multi-colinearity problem between the explanatory variables.

Before conducting any econometric study, it is necessary to ensure that the explanatory variables do not communicate the same information. The existence of a multi-linearity problem is explained by the high correlation between the explanatory variables. The study of the correlation matrix allows us to detect the existence or not of a multi-linearity problem. The correlation study between the variables gives an idea of the statistical link between them. It allows us to verify the hypothesis of the independence of the explanatory variables and thus to detect the problem of multi-colinearity. Obtaining strong correlation coefficients raises the problem of multi-colinearity between the values of two variables. This multi-colinearity becomes more important as the coefficients approach 1 .

In our study, we notice a low correlation between the different explanatory variables (the majority of the variables have a correlation coefficient lower than 0.7 ), which shows the absence of the problem of multi-collinearity. Therefore we can introduce all the variables in the same model.

Table 4. Correlation matrix.

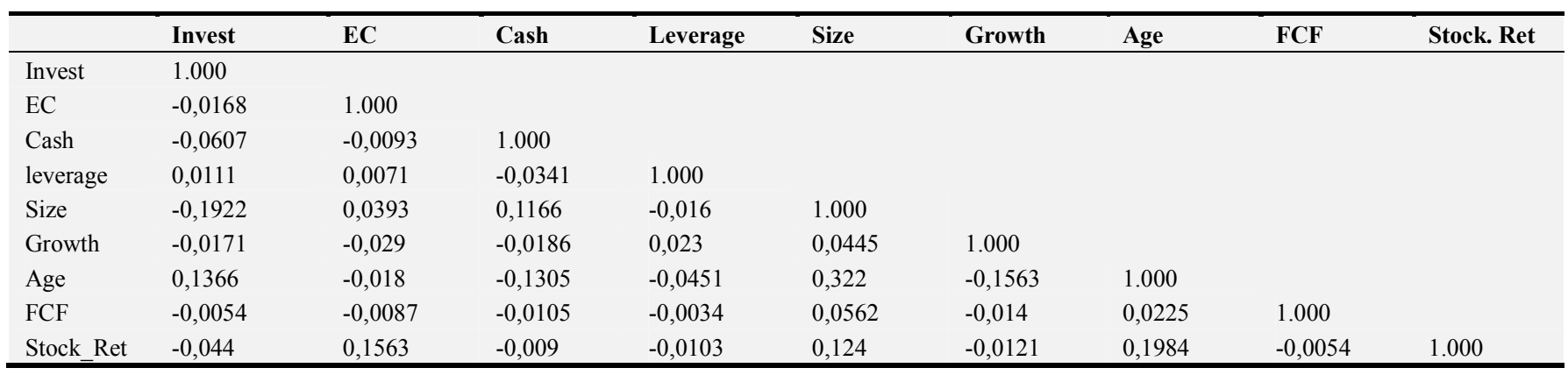




\subsection{Normality Tests}

Table 5. Results of the normality tests.

\begin{tabular}{|c|c|c|c|c|}
\hline Variables & Pr (skewness) & $\operatorname{Pr}$ (kurtosis) & Chi2 (2) & Prob (chi2) \\
\hline Invest & 0.0000 & 0.0000 & & 0.0000 \\
\hline Overconfid & 0.0000 & 0.0000 & & 0.0000 \\
\hline Cash & 0.0000 & 0.0000 & & 0.0000 \\
\hline Leverage & 0.0000 & 0.0000 & & 0.0000 \\
\hline Size & 0.0000 & 0.0000 & & 0.0000 \\
\hline Growth & 0.0000 & 0.0000 & & 0.0000 \\
\hline Age & 0.0000 & 0.0000 & 66,1 & 0.0000 \\
\hline FCF & 0.0000 & 0.0000 & & 0.0000 \\
\hline Stock. Ret & 0.0000 & 0.0000 & & 0.0000 \\
\hline
\end{tabular}

We also find that the dependent and independent variables of the firms exhibit a positive skewness coefficient; hence the distribution of these variables has a tail elongated towards the right. Conversely, the variables have a skewness coefficient with a positive sign, which means that the distribution of the latter has a tail elongated to the right. We also note that the skewness coefficients for all the variables are almost zero.

As for the kurtosis coefficient, we notice that all distributions have a coefficient greater than 3, so they are leptokurtic (the presence of thick tails). We can accept the hypothesis of normality of some values during the period of our study that extends from 2009 until 2018, that is, there are no excessive deviations from the mean.

\subsection{Stationarity Test}

Before estimating our model, we need to check the variables stationarity. Indeed, the stationarity analysis is a prerequisite to avoid spurious regressions.

Table 6. Stationarity tests of Fisher and Choi [58].

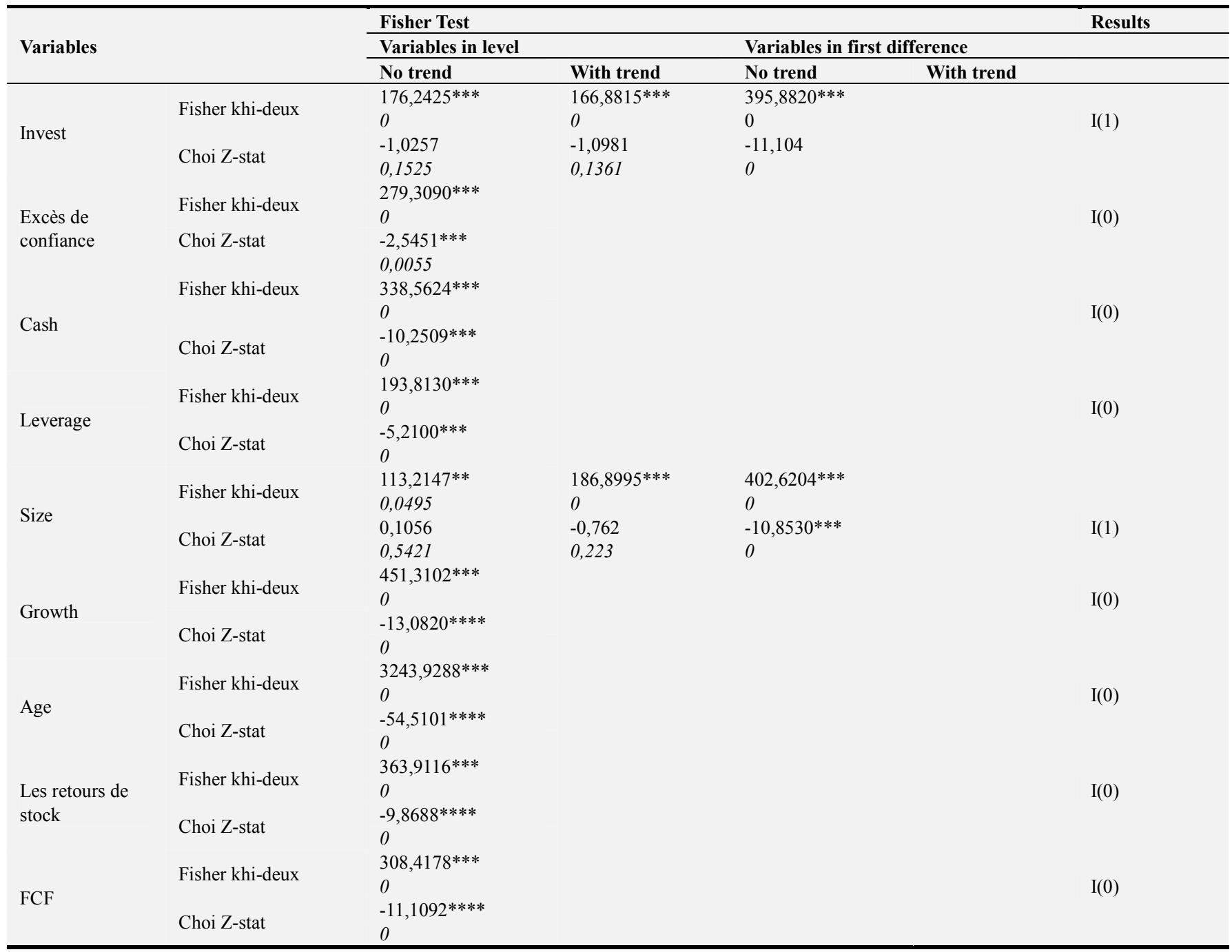

Notes: $* * *$ variables are significant at the $1 \%$ level, $* *$ variables are significant at the $5 \%$ level

$\mathrm{I}(0)$ : indicates that the series is stationary in level.

I(1): indicates that the series is stationary in first difference.

$\mathrm{I}(2)$ : indicates that the series is stationary in second difference

The table below presents the results of the panel unit root tests in levels and in first difference for each variable executed in three types: test in levels not including the trend term, test in levels including the time trend and finally test 
including the first difference without and with trend.

Over the last few years, several procedures have been recommended for testing for the presence of unit roots with panel data techniques. The main difference between them concerns the assumptions about the heterogeneity of the model. This heterogeneity was first introduced via fixed effects and then via dynamic autoregressive structures.

A variable is integrated of order I(1) if this variable is nonstationary in level but stationary in first difference. A variable is integrated of order I(0) if it is stationary in level and in first difference.

The tables present the stationarity results for the different variables according to the Fisher and Choi tests [58] tests. We can see that the variables (excess confidence, cash, leverage, growth, age of the firm, stock returns and FCF) are stationary in level, the two variables "Investment" and "Size of the firm" are stationary in first difference, so we can use the standard estimation techniques because there is no risk of spurious regression.

\subsection{Heteroscedasticity Test}

The Breusch-Pagan statistic is obtained after the estimation of the model. It allows to test the significance of the model. If the probability of the Breusch-Pagan statistic is higher than the higher than the fixed threshold (5\%), thus the absence of a heteroscedasticity problem.

The test is based on the following assumptions:

1) H0: No heteroscedasticity problem

2) H1: Presence of heteroskedasticity problem

Table 7. Results of the Heteroscedasticity Test.

\begin{tabular}{lll}
\hline & Test de Breusch-Pagan & Test de Breusch-Pagan \\
\cline { 2 - 3 } & Modèle 1 & Modèle 2 \\
\hline Khid-deux & 580,95 & 14,66 \\
p-value & 0 & 0,0001 \\
\hline
\end{tabular}

For the two models of our sample of 45 Tunisian companies retained, it emerges that the Chi-square tests are not significant at the threshold of $5 \%$ then we can accept $\mathrm{H} 1$; the application of the test of homogeneity on our model shows the presence of the problem of heterogeneity (heterosedasticity).

\subsection{Autocorrelation Test}

We detected autocorrelation by the Breusch Godfrey Serial Correlation LM Test. The test is based on the following assumptions:

1) H0: No autocorrelation

2) H1: Presence of autocorrelation

Table 8. Results of the Breusch-Godfrey Serial Correlation LM Test.

\begin{tabular}{lll}
\hline & Breusch-Godfrey Serial Correlation LM Test & Breusch-Godfrey Serial Correlation LM Test \\
\cline { 2 - 3 } & Modèle 1 & Modèle 2 \\
\hline Khid-deux & 250,169 & 262,851 \\
p-value & 0 & 0 \\
\hline
\end{tabular}

The Breusch-Godfrey Serial Correlation LM Test for both models are significant at the $5 \%$ level, so we accept $\mathrm{H} 1$ and conclude that there is a correlation between the errors.

To conduct this empirical analysis, we begin by noting that unlike Richardson [52] and Chen et al. [59] who use the static fixed-effects panel as their estimation method, we interrogated the dynamic panel method of the GMM system, which resolves the problems of heteroskedasticity and autocorrelation.

\subsection{Tests Associated with the GMM Estimator in System}

Two tests are associated with the GMM estimator in system:

Sargan and Hansen over-identification test:

It tests the validity of the lagged variables as instruments.

1) H0: the instruments are valid.

2) $\mathrm{H} 1$ : the instruments are not valid.

A. Model 1:

Chi $2(35)=6,889572$

Prob $>$ chi $2=1.0000$

$\mathrm{H} 0$ : So the instruments are valid.

B. Model 2:

Chi $2(5)=354,4425$

Prob $>$ chi $2=0,3656$

H0: So the instruments are valid.
Autocorrelation test of Arellano and Bond [56]

It is used to test the autocorrelation between the variables and the error term.

1) H0: no first-order autocorrelation between the variables and the error term.

2) H1: absence of second order autocorrelation between the variables and the error term.

Model 1

$\begin{array}{lll}\text { Order } & z & \text { Prob }>z \\ 1 & -2,1495 & 0,0316 \\ 2 & -1,0208 & 0,3073\end{array}$

$\mathrm{H} 0$ is validated, no second order autocorrelation between the variables and the error term.

Model 2

$\begin{array}{lll}\text { Order } & \mathrm{Z} & \text { Prob }>\mathrm{Z} \\ 1 & -4,3536 & 0,0000 \\ 2 & -0,68519 & 0,4932\end{array}$

$\mathrm{H} 0$ is validated, no second order autocorrelation between the variables and the error term.

\section{Interpretation and Estimation Results Discussion}

The results of the estimations are presented in the 
following table:

Table 9. Estimation results summary.

\begin{tabular}{lll}
\hline \multirow{2}{*}{ Independent Variables } & \multicolumn{2}{l}{ (Dependant Variable) Investment } \\
\cline { 2 - 3 } & Model 1 & Model 2 \\
\hline Investment $_{i, t-1}$ & $0,532^{* * *}(11,86)$ & $0,590^{* * *}(15,72)$ \\
Overconfidence $_{i, t}$ & $0,030^{* *}(2,31)$ & $0,018^{*}(1,82)$ \\
Cash $_{i, t}$ & $0,012^{* *}(1,97)$ & \\
Leverage $_{i, t}$ & $-0,396^{* *}(-2,06)$ & \\
Size $_{i, t}$ & $0,543^{* *}(2,11)$ & \\
Growt $_{i, t}$ & $-0,404^{* * *}(-5,35)$ & \\
Age $_{i, t}$ & $-0,305^{* * *}(-2,65)$ & \\
Stock returns $_{i, t}$ & $-0,020(-0,020)$ & \\
FCF & & $0,031 * * *(3,18)$ \\
Wald khi-deux & & 260,49 \\
Prob $>$ khi-deux & 251,78 & 0,0000 \\
Test de Hansen & 0,000 & 354,4425 \\
Prob $>$ Hansen & 6,889572 & 0,3656 \\
AR $(1)$ (Prob $>$ z) & 1,0000 & 0,0000 \\
AR $(2)$ (Prob $>$ z) & 0,0316 & 0,4932 \\
Number of observations & 0,3073 & 450 \\
\hline
\end{tabular}

Notes: $* * *, * * *$, Variables are significant at $1 \%, 5 \%$ and $10 \%$ level, respectively.

To begin the empirical analysis, we first highlight that unlike Richardson [56] and Chen et al. [59], who use the static fixed effects panel as an estimation method, we used the dynamic panel method of the GMM system, which addresses the problems of heteroskedasticity and autocorrelations. In both models, we notice that the $\mathrm{H} 0$ hypothesis of the validity of the instruments is not rejected. Indeed, the probability of the Hansen statistic is greater than $5 \%$, implying that the instruments are generally exogenous. In addition, the probabilities of the Arellano and Bond test of AR (2) are greater than 5\%, implying that there is no second order serial autocorrelation. Regarding the overall significance of the model, it turns out that both models show a Wald test probability of 0.000 that is significantly less than $5 \%$, which proves that both models are significant overall.

Our study period starts in 2009 and ends in 2018, a period characterized by a remarkable event which is the Tunisian revolution in 2011. In this work, we will study the effect of financial distress on firms' debt policy and how Tunisian listed firms react in a case of financial distress by manipulating their debt levels. In addition, a major event such as the revolution can have an effect on the investment policies of companies.

In this case, we can examine the individual significance of each of the explanatory variables explanatory variables. To begin with, the regression results (see table 9) allow us to deduce a positive influence of the dependent variable "Investment" on the variable "delayed investment". The regression coefficient is of the order of (0.532) with a significance level of 0.000 in model (1), in addition, in model (2), with the presence of the variable "FCF", the regression coefficient is of the order of $(0.590)$ with a significance level of 0.000 . Student's $t$ is 11.86 for model (1) and 15.72 for model (2), thus exceeding the commonly accepted bound (1.96). This suggests that the lagged variable "investment expenditure" of the previous year positively influences the dependent variable "investment expenditure" of the current year.

As for the "EC" variable (Overconfidence), the literature suggests a positive relationship between managerial overconfidence and the investment decision of firms. This relationship seems to be confirmed by the regression analysis (see table above).

The coefficients of the "Overconfidence" variable are positive $(\beta=0,030)$ for model 1 and $(\beta=0,018)$ for model (2) and significant at the $5 \%$ level in both model $1(\mathrm{p}=0,021)$, as well as model $2(\mathrm{p}=0,069)$ with the presence of the cash flow costs, in addition, Student's t exceeds the norm (1.96) and amounts to 2.31 (Model 1) and exceeds the norm of (1.67) by 1.82 (Model 2). This indicates that "Overconfidence" is positively associated with firms' investment decision. Thus, our hypothesis that managerial overconfidence positively influences the investment decision of firms is confirmed.

These findings suggest that an overconfident manager overestimates the probability of success of investment projects by believing that he or she has all the necessary information accurately, consistent with previous work such as Daniel et al, [60] and Acker and Duck, [61]), and overestimates the impact of his or her effort on the success of the project Fairchild [62]).

Other studies such as those of Heaton, Hackbarth, Gervais et al., Malmendier and Tate, Goel and Thakor, Malmendier et al. provide an alternative explanation to the sensitivity of investment to cash flow [3, 63-64, 46, 5, 24, 65, 4]. According to them, an overconfident manager overestimates the return on his project and prefers self-financing to finance his investment choices and limits the use of external financing methods since he considers that his company is undervalued by the market. This implies the presence of a positive effect between the overconfidence of the manager and the choice of self-financing.

Globally, our results were similar to previous results showing that the leader overestimates his own skills and knowledge (Langer, [39]), which is called "The better than average" (Camerer and Lovallo, [27]). Within this framework, research in corporate finance, both theoretical and empirical, has focused on the behavioral biases of managers and their impact on decision making. Given our empirical results, they are fully consistent with the results of Doukas and Petmezas, Ye and Yuan, Grundy and Li, Chen and Lin, Ben Mouhamed, Fairchild \& Bouri, and Wang et al., [49, 66-71], we note that highly confident managers with positive free cash flows tend to overinvest. This result, like Barros \& Silveira ([44]), demonstrates that overconfident managers overestimate their capabilities and thus overemphasize their personal information or perspective. Xiao \& Zhou ([45]) counter says this hypothesis and show that managerial overconfidence is not an essential ingredient for good investment decision making. Instead, they show that managerial overconfidence combined with free cash flow amplifies investment spending.

To enhance our empirical tests, we used behavioral finance and more specifically overconfidence as well as its possible 
effect on the investment of free cash flows. In this regard, Kramer \& Liao ([72]) and Ahmed \& Duellman ([73]) argue that the overconfident manager overestimates the return on investment and therefore intends to delay the recognition of losses. This leads this manager type to view negative NPV projects as positive NPV projects, thereby increasing the risk of the investment. This acquiescence was recently validated by Hribar \& Yang ([74]), who show that overconfidence leads the manager to overestimate future expectations. For instance, to test the effect of overconfidence and cash flow on the investment decision, Richardson ([52]) and Chen et al. ([75]), introduced an interaction variable between free cash flow and overconfidence. The results of this work state that investment increases with managerial overconfidence.

Based on the empirical evidence, it is consistent with the second research hypothesis that manager behavioral bias, manifested as overconfidence, can exacerbate the free cash flow investment problem. The investment decision is one of many very important decisions that managers must make and can be affected by managerial characteristics.

From the findings found by El Gaied Moez and Zgarni Amina ([26]), it should be established that the degree of overconfidence of managers is a variable that manages free cash flow investment. Consistent with $\mathrm{Lu} \& \mathrm{Liu}$ ([76]), it is found that overconfident managers are more likely to engage in free cash flow investment. Moreover, these results lead us back to the idea that highly confident managers with negative free cash flows may overinvest. Indeed, we note that the coefficient associated with the variable $(F C F<0)$ is positive and statistically significant at the $1 \%$ level. Thus, as Huang, Jiang, Liu and Zhang ([22]), it seems to be accepted that the overconfidence of the manager, shows a psychological bias, which can mislead the investment decision and consequently destroy the performance of the company. This result was confirmed by Heaton ([3]), for which overconfidence, fueled at the same time by distinguished free cash flow, led to the waste of free cash flow, which is reflected in increased capital expenditure.

The regression results found by El Gaied Moez and Zgarni Amina ([26]) stipulate the acceptance of the research hypothesis that firms with free cash flow are able to invest. Indeed, these results which coincide with those of Tangjitprom [77] and Guarglia \& Yang [78], demonstrate and confirm that managers are opportunistic and empire builders, an idea initiated by Jensen [79]. This suggests that firms with positive free cash flows are more likely to engage in investment than firms with negative free cash flows.

We use a second control variable "level of liquidity" or "cash" to measure the impact of this variable on the investment decision of firms. The regression results (see table) allow us to deduce a positive influence of the level of liquidity on investment spending.

The regression coefficient is $(\beta=0,012)$ for model ( 1$)$, so the coefficient on the Cash variable is correspondingly positive and significant $(\mathrm{p}=0.049<0.05)$. Student's $\mathrm{t}$ is 1.97 , exceeding the commonly accepted bound (1.96), which suggests that the level of liquidity for firms does explain the correct investment decision of firms. Thus, the expected hypothesis of a positive relationship between the level of liquidity and the investment decision is confirmed. Consistent with the results of Richardson [52] and El Gaied Moez and Zgarni Amina [26], investment spending increases with the level of liquidity (Cash).

The variable "Leverage" influences negatively and significantly the investment expenses of Tunisian firms listed on the stock exchange. The variable short and long term debt admits an effect negatively ( $\beta=-0,396)$ significant at the $5 \%$ threshold $(0.039)$. That is to say that the higher the debts the lower the investment expenditure is and conversely, this is consistent with the idea that indicates that the more that the company has easy recourse to debt, the more that its liquid assets are less. So as stated by Richardson [52] and El Gaied Moez and Zgarni Amina [26], capital expenditures decrease from the firm with its short and long-term debt (Leverage).

Depending on the results of our model, firm size admits a positive $(\beta=0,543)$ and significant effect at the $5 \%$ level $(0.035)$ on the investment decision depending on the variable used, LACTIF is significant at the 5\% level. According to these results, investment spending increases with firm size (SIZE). In line with previous work such as the work of Richardson [52] and El Gaied Moez and Zgarni Amina [26], the large size of a firm represents a guarantee for the firm, managers following this guarantee neglect the investment decision and do not stop increasing their investment levels, the larger the size, the better the investment decisions are then.

Based on these results from the dynamic panel regression, it appears that the financial variable (sales growth) "Growth" contributes significantly to the determination of capital expenditures. Expected investment spending decreases with the "Sales Growth" variable in model (1), which could lead to an improvement in the explanatory power of the model. Indeed, the estimated coefficient on the "Growth" variable $(\beta=-0,404)$ is statistically significant at the $1 \%$ level $(p=0,000<0,01)$ in the model. As a result, similar to Richardson [52] and El Gaied Moez and Zgarni Amina [26], we find that sales growth decreases new investment spending by firms.

As per the empirical results, the age of the firm admits a negative and significant effect on investment expenditure, the age of the firm is significant at the $1 \%$ threshold $(p=$ $0,008<0,01)$ with a negative coefficient $(\beta=-0,305)$. According to these results, the investment expenditure in the previous year decreased with the age of the firm (Age). Consistent with previous work such as the work of Richardson [52] and El Gaied Moez and Zgarni Amina [26], the newly created firm represents a guarantee for new investments and subsequently to a good investment decision.

Ultimately, and with respect to the variable "Stock Returns" according to the empirical results exerts no influence $(\beta=-0,020$ and $p=0,759>0,05)$ on the investment spending of Tunisian firms. These results diverge with the results found by Richardson [52] and El Gaied Moez and Zgarni Amina [26], which stipulate that stock returns increase firms' investment spending. 


\section{Conclusions and Implications}

The main objective of this research is to examine the impact of overconfidence on the investment behavior of the manager in Tunisian listed companies. Thus, to test the effect of the manager's overconfidence on the investment decision, we based on a simple investment model to show that in the presence of the manager's overconfidence the sensitivity of the investment to the cash flows is stronger. Similarly, we then construct a proxy composed of both the manager's compensation and his decision power. The latter is measured by the inverse of the number of managers in the management team. All other things being equal, the lower the number of managers, the greater the manager's decision-making power. This second component of our chosen proxy, decision power, draws its logic from the fact that it gives the manager a sense of being the most important and the primary decision maker, which may lead him or her to overestimate his or her abilities and skills. Brown and Sarma, Doukas and Petmezas, Jenter, Jin and Kothari [48-51]. In addition, we regressed the interaction between cash flow and managerial overconfidence and managerial overconfidence, the measure of overconfidence after analyzing the investment on cash flows. As a result, a strong prediction between management overconfidence and investment-cash-flow sensitivity. For all measures, the majority of the coefficients is significant and expected signs.

Our finding in this scientific article is that overconfidence as a psychological characteristic of the manager is strongly present in all stages of corporate decision making, including investment. To summarize, the area of behavioral finance that was examined with the link between managerial overconfidence and investment is a small part of the overall work. Indeed, there are other unexplored areas of research available in relation to managerial overconfidence and corporate decision making, particularly in relation to dividends and capital structure.

In conclusion, the results obtained have opened our horizons for a future expansion of this work. In particular, we recommend revisiting the proxies used to understand certain variables, as the selection and measurement of these variables are often problematic. As a matter of fact, some of the basic variables underlying the theoretical financial model we are working on are either unmeasured or imperfect, such as overconfidence. In addition, it seems relevant and interesting to distinguish between state-controlled listed companies and management companies among the groups of firms in our sample. While the shareholder-manager relationship of these two types of companies is similar, this does not hide the differences in the motivation of the managers of these companies and the systems of control of their managers.

\section{References}

[1] Baker, M., Ruback, R. S., \& Wurgler, J. (2007). Behavioral corporate finance. In Handbook of empirical corporate finance (pp. 145-186). Elsevier.
[2] Hackbarth, D. (2008). Managerial traits and capital structure decisions. Journal of financial and quantitative analysis, 43 (4), 843-881.

[3] Heaton, J. B. (2005). Managerial optimism and corporate finance. In Advances in Behavioral Finance, Volume II (pp. 667-684). Princeton University Press.

[4] Malmendier, U., Tate, G., \& Yan, J. (2011). Overconfidence and early-life experiences: the effect of managerial traits on corporate financial policies. The Journal of finance, 66 (5), 1687-1733.

[5] Malmendier, U., \& Tate, G. (2008). Who makes acquisitions? CEO overconfidence and the market's reaction. Journal of financial Economics, 89 (1), 20-43.

[6] Cordeiro, L. (2009). Managerial Overconfidence and Dividend Policy (SSRN Scholarly Paper ID 1343805). Social Science Research Network. https://papers.ssrn.com/abstract=1343805.

[7] Deshmukh, S., Goel, A. M. and al. (2013). CEO overconfidence and dividend policy, Journal of Financial Intermediation, 22 (3), 440-463.

[8] Jensen, M. C. and Meckling, W. H. (1976). Theory of the firm: Managerial behavior, agency costs and ownership structure, Journal of Financial Economics, 3 (4), 305- 360.

[9] Myers, S. C. and Majluf, N. S. (1984). Corporate financing and investment decisions when firms have information that investors do not have, Journal of Financial Economics, 13 (2), $187-221$.

[10] Fazzari F., Hubbard R., Petersen B. [1988], "Financing Constraints and Corporate Investment", Brookings Papers on Economic Activity.

[11] Hubbard and Peterson (2000), "Capital Market imperfections and investment", Journal of Economic Literature, 36 (3), pp. 193-225.

[12] Kaplan, S. N., \& Zingales, L. (1997). Do investment-cash flow sensitivities provide useful measures of financing constraints?. The quarterly journal of economics, 112 (1), 169215 .

[13] Kaplan, S. N., \& Zingales, L. (2000). Investment-cash flow sensitivities are not valid measures of financing constraints. The Quarterly Journal of Economics, 115 (2), 707-712.

[14] Kahneman, D., \& Lovallo, D. (1993). Timid choices and bold forecasts: A cognitive perspective on risk taking. Management science, 39 (1), 17-31.

[15] Shefrin, H. (2001). Behavioral corporate finance. Journal of applied corporate finance, 14 (3), 113-126.

[16] Goel, A. M. and Thakor, A. V. (2000). Overconfidence, CEO selection, and corporate governance, Journal of Finance, 63 (6), 2737-2784.

[17] Malmendier, U., \& Tate, G. (2001). CEO overconfidence and corporate investment. Mimeo, Havard University.

[18] Gervais, S., Heaton, J. B., \& Odean, T. (2002). The positive role of overconfidence and optimism in investment policy.

[19] Malmendier, U., \& Tate, G. (2009). Superstar ceos. The Quarterly Journal of Economics, 124 (4), 1593-1638. 
[20] Campbell, T. C., Gallmeyer, M., Johnson, S. A., Rutherford, J., \& Stanley, B. W. (2011). CEO optimism and forced turnover. Journal of Financial Economics, 101 (3), 695-712.

[21] Lin, Y. H., Hu, S. Y., \& Chen, M. S. (2005). Managerial optimism and corporate investment: Some empirical evidence from Taiwan. Pacific-Basin Finance Journal, 13 (5), 523-546.

[22] Huang, W., Jiang, F., Liu, Z., \& Zhang, M. (2011). Agency cost, top executives' overconfidence, and investment-cash flow sensitivity-Evidence from listed companies in China. Pacific-Basin Finance Journal, 19 (3), 261-277.

[23] Glaser, M., \& Schmitz, P. (2007). Privatanleger am Optionsscheinmarkt. Zeitschrift für Bankrecht und Bankwirtschaft, 19 (3), 214-230.

[24] Malmendier, U., \& Tate, G. (2005a). Does overconfidence affect corporate investment? CEO overconfidence measures revisited. European financial management, 11 (5), 649-659.

[25] Malmendier, U., \& Tate, G. (2005b). CEO overconfidence and corporate investment. The journal of finance, 60 (6), 26612700 .

[26] Moez, E. G., \& Amina, Z. (2018). Overinvestment of free cash flow and manager's overconfidence. International Business Research, 11 (3), 48-57.

[27] Camerer, C., \& Lovallo, D. (1999). Overconfidence and excess entry: An experimental approach. American economic review, 89 (1), 306-318.

[28] McConnell, J. J., \& Muscarella, C. J. (1985). Corporate capital expenditure decisions and the market value of the firm. Journal of financial economics, 14 (3), 399-422.

[29] Byrd, J., Parrino, R., \& Pritsch, G. (1998). Stockholdermanager conflicts and firm value. Financial Analysts Journal, $54(3), 14-30$

[30] Narayanan, M. (1985). Managerial incentives for short-term results. The Journal of Finance, 40 (5), 1469-1484.

[31] Thurow, L. (1992). Head to head: The coming economic battle among Japan. Europe and America (NY: Warner, 1992).

[32] Porter, M. E. (1992). Capital disadvantage: America's failing capital investment system. Harvard business review, 70 (5), 65-82.

[33] Larwood, L., \& Whittaker, W. (1977). Managerial myopia: Self-serving biases in organizational planning. Journal of applied psychology, 62 (2), 194.

[34] Svenson, O. (1981). Are we all less risky and more skillful than our fellow drivers?. Acta psychologica, 47 (2), 143-148.

[35] Alicke, M. D. (1985). Global self-evaluation as determined by the desirability and controllability of trait adjectives. Journal of personality and social psychology, 49 (6), 1621.

[36] Kidd, J. B. (1970). The utilization of subjective probabilities in production planning. Acta psychologica, 34, 338-347.

[37] Weinstein, N. D. (1980). Unrealistic optimism about future life events. Journal of personality and social psychology, 39 (5), 806 .

[38] March, J. G., \& Shapira, Z. (1987). Managerial perspectives on risk and risk taking. Management science, 33 (11), 14041418 .
[39] Langer, E. J. (1975). The illusion of control. Journal of personality and social psychology, 32 (2), 311.

[40] Alicke, M. D., Klotz, M. L., Breitenbecher, D. L., Yurak, T. J., \& Vredenburg, D. S. (1995). Personal contact, individuation, and the better-than-average effect. Journal of personality and social psychology, 68 (5), 804.

[41] Roll, R. (1986). The hubris hypothesis of corporate takeovers. Journal of business, 197-216.

[42] Hovakimian, A., \& Hovakimian, G. (2009). Cash flow sensitivity of investment. European Financial Management, $15(1), 47-65$.

[43] Campbell, C., Johnson, S., Rutherford, J., \& Stanley, B. (2009). CEO confidence and forced turnover. Journal of Financial Economics, 101 (3), 695-712.

[44] Barros, L., \& Silveira, A. (2008). Overconfidence, Managerial Optimism, and the Determinants of Capital Structure. Brazilian Review of Finance, 6 (3), 293-335.

[45] Longjie, X., \& Anfeng, Z. (2017). The impact of managers overconfidence on corporate investment. International Journal of Social Science and Humanity, 7 (2), 109-114.

[46] Gervais, S., Heaton, J. B., \& Odean, T. (2003). Overconfidence, investment policy, and executive stock options. Rodney L. White Center for Financial Research Working Paper, 15 (02).

[47] Malmendier, U., Tate, G., \& Yan, J. (2007). Corporate financial policies with overconfident managers.

[48] Brown, R., \& Sarma, N. (2007). CEO overconfidence, CEO dominance and corporate acquisitions. Journal of Economics and business, 59 (5), 358-379.

[49] Doukas, J. A., \& Petmezas, D. (2007). Acquisitions, overconfident managers and self-attribution bias. European Financial Management, 13 (3), 531-577.

[50] Jenter, D. (2005). Market timing and managerial portfolio decisions. The Journal of Finance, 60 (4), 1903-1949.

[51] Jin, L., \& Kothari, S. P. (2008). Effect of personal taxes on managers' decisions to sell their stock. Journal of Accounting and Economics, 46 (1), 23-46.

[52] Richardson, S. (2006). Over-investment of free cash flow. Review of accounting studies, 11 (2-3), 159-189.

[53] Anderson, T. W., \& Hsiao, C. (1982). Formulation and estimation of dynamic models using panel data. Journal of econometrics, 18 (1), 47-82.

[54] Sevestre, P., \& Trognon, A. (1996). Dynamic linear models. In The Econometrics of Panel Data (pp. 120-144). Springer, Dordrecht.

[55] Blundell, R., \& Bond, S. (1998). Initial conditions and moment restrictions in dynamic panel data models. Journal of econometrics, 87 (1), 115-143.

[56] Arellano, M., \& Bond, S. (1991). Some tests of specification for panel data: Monte Carlo evidence and an application to employment equations. The review of economic studies, 58 (2), 277-297.

[57] Hergli, S., \& Teulon, F. (2013). Déterminants de la structure du capital: le cas tunisien. Gestion 2000, 30 (5), 49-73. 
[58] Ficher and Choi, I. (2002), iCombination Unit Root Tests for Cross-Sectionally Correlated Panelsî, Mimeo, Hong Kong University of Science and Technology.

[59] Chen, C., Chen, Y., Hsu, P. H., \& Podolski, E. J. (2016). Be nice to your innovators: Employee treatment and corporate innovation performance. Journal of corporate finance, 39, 7898.

[60] Daniel, K. D., Hirshleifer, D., \& Subrahmanyam, A. (2001). Overconfidence, arbitrage, and equilibrium asset pricing. The Journal of Finance, 56 (3), 921-965.

[61] Acker, D., \& Duck, N. W. (2008). Cross-cultural overconfidence and biased self-attribution. The Journal of Socio-Economics, 37 (5), 1815-1824.

[62] Fairchild, L., \& Li, J. (2005). Director quality and firm performance. Financial Review, 40 (2), 257-279.

[63] Hackbarth, D. (2002, December). Managerial optimism, overconfidence, and capital structure decisions. In European Finance Association Annual Meeting, (Aug, 2004), Maasticht, The Netherlands.

[64] Hackbarth, D. (2004). Determinants of corporate borrowing: A behavioral perspective. Journal of Corporate Finance, 15 (4), 389-411.

[65] Goel, A. M., \& Thakor, A. V. (2008). Overconfidence, CEO selection, and corporate governance. The Journal of Finance, 63 (6), 2737-2784.

[66] Ye, B., \& Yuan, J. (2008). Firm value, managerial confidence, and investments: The case of China. Journal of Leadership studies, 2 (3), 26-36.

[67] Grundy, B. D., \& Li, H. (2010). Investor sentiment, executive compensation, and corporate investment. Journal of Banking \& Finance, 34 (10), 2439-2449.

[68] Chen, I. J., \& Lin, S. H. (2012). Will managerial optimism affect the investment efficiency of a firm?. Procedia Economics and Finance, 2, 73-80.

[69] Chen, H. J., \& Lin, S. H. (2013). Managerial optimism, investment efficiency, and firm valuation. Multinational Finance Journal, 17 (3/4), 295-340.
[70] Mohamed, E. B., Fairchild, R., \& Bouri, A. (2014). Investment cash flow sensitivity under managerial optimism: New evidence from NYSE panel data firms. Journal of Economics Finance and Administrative Science, 19 (36), 1118.

[71] Wang, Y., Chen, C. R., Chen, L., \& Huang, Y. S. (2016). Overinvestment, inflation uncertainty, and managerial overconfidence: Firm level analysis of Chinese corporations. The North American Journal of Economics and Finance, 38, 54-69.

[72] Kramer, L. A., \& Liao, C. M. (2012, May). The Cost of False Bravado: Management Overconfidence and its Impact on Analysts' Views. In North American finance conference.

[73] Ahmed, A. S., \& Duellman, S. (2013). Managerial overconfidence and accounting conservatism. Journal of accounting research, 51 (1), 1-30.

[74] Hribar, P., \& Yang, H. (2016). CEO overconfidence and management forecasting. Contemporary accounting research, 33 (1), 204-227.

[75] Chen, H. K., Chen, Y. S., Huang, C. W., \& Wang, Y. (2009). Managerial responses to initial market reactions on share repurchases. Review of Pacific Basin Financial Markets and Policies, 12 (03), 455-474.

[76] Lu, W., \& Liu, H. (2016, June). The empirical study on the relation between managerial overconfidence and overinvestment. In 2016 13th International Conference on Service Systems and Service Management (ICSSSM) (pp. 1-6). IEEE.

[77] Tangjitprom, N. (2015). Over-investment and free cash flow: Evidence from Thailand. In International Conference on Business, Economics and Management (ICBEM'15) April (pp. 9-10).

[78] Guariglia, A., \& Yang, J. (2016). A balancing act: managing financial constraints and agency costs to minimize investment inefficiency in the Chinese market. Journal of Corporate Finance, 36, 111-130.

[79] Jensen, M. C. (1986). Agency costs of free cash flow, corporate finance, and takeovers. The American economic review, 76 (2), 323-329. 